\title{
研究論文
}

\section{2. 中性子放射化によるカリウムの同位体分析法の研究}

\author{
品川睦明*, 大吉 昭*, 大吉僓美子* \\ On the Determination of the Isotopic Composition of Potassium \\ by Neutron Activation
}

By Mutsuaki SHINAGAWA, Akira ŌYOSHI and Emiko ŌYOSHI

\begin{abstract}
The isotopic ratio of ${ }^{41} \mathrm{~K} /{ }^{39} \mathrm{~K}$ was determined by neutron activation analysis. About $100 \mathrm{mg}$ of potassium nitrate sample was treated in fused state with zirconyl phosphate as ion exchanger to separate the isotope, and irradiated for $10 \mathrm{~min}$ in JRR-1. Potassium nitrate was taken as standard reference sample possessing the natural isotopic ratio and irradiated in the same manner. After irradiation, the activity of ${ }^{42} \mathrm{~K}$ produced by the ${ }^{41} \mathrm{~K}(n, \gamma)^{42} \mathrm{~K}$ reaction was measured with a 256 channel pulse height analyzer. The isotopic ratio of unknown samples were calculated from the specific activities of the unknown and standard samples. The separation ratio $E$ is defined as follows: $E=$ $\left[{ }^{41} \mathrm{~K} /{ }^{39} \mathrm{~K}\right]$ unknown $/\left[{ }^{41} \mathrm{~K} /{ }^{39} \mathrm{~K}\right] \mathrm{std}$. $=S_{b} / S_{r a}$ where $S_{a}$ and $S_{b}$ are specific activities of the unknown and the standard samples, respectively. The result of neutron activation was slightly affected by the irradiation geometry of the samples, but the ununiformity of neutron flux could be calibrated by parallel tests using standard samples. While the results obtained, were not quite as accurate as mass-spectrometrical data, they were fairly correct, and the proposed method could be used in many ways as a convenient technique where a number of samples must be analyzed at the same time.
\end{abstract}

\section{I. 緒 言}

現在同位体比の測定法としては，質量分析法が最も 一般的でり，かつ確聿な方法として知られている。 しかし簡便のため，他の方法に上る同位体比測定法を 場合によっで考憵せねばならない。その1つとして 原子核反応利用し，同位体の核特性の差璂つく分 析法がある。この方法については， $(n, \alpha) ，(n, f)$ 反応 に上る $\mathrm{Li}, \mathrm{B}, \mathrm{U}^{(1)},(n, \gamma)$ 反応に上る $\mathrm{Hf}, \mathrm{Os}_{\mathrm{S}}, \mathrm{W}^{(2)}$ ， $(n, \gamma),(n, f)$ 反応によるU U(3) の同位体分析に関する報 文がある。さらに ${ }^{6} \mathrm{Li}(n, \alpha){ }^{3} \mathrm{H},{ }^{18} \mathrm{O}(t, n){ }^{18} \mathrm{~F}$ 反応の上 5 な 2 次的に起る反応を利用した Li の同位体分析(4). または $\left.{ }^{10} \mathrm{~B}(n, \alpha)\right)^{7} \mathrm{Li},{ }^{55} \mathrm{Mn}(n, \gamma){ }^{56} \mathrm{Mn}$ なる反応によっ て生じた ${ }^{56} \mathrm{Mn}$ の放射能を測定して， ${ }^{10} \mathrm{~B}$ の量を相対 的に測定する方法(5)などる報告されている。

本研究は同位体分離を行なったカリウム(硝酸カリ ウム)の同位体組成を定めるため， ${ }^{41} \mathrm{~K}(n, \gamma){ }^{42} \mathrm{~K}$ 反応
を利用し， ${ }^{42} \mathrm{~K} の$ 放射能測定值の比較により，カリウ ムの同位体組成の相対的測定を行ない，啠量分析の結 果と比較して，その適否の検尉を行なったものであ る。

\section{II. 試料と装置}

1. 試数

（1）岸田化学(株)製特級試薬硝酸カリウムを用い, 文㶓值 ${ }^{6},{ }^{39} \mathrm{~K}: 93.08 \%,{ }^{40} \mathrm{~K}: 0.0119 \%,{ }^{41} \mathrm{~K}: 6.91$ \%の組成をるつ標华試料として取り扱った。

（2）融解硝酸カリウムとリン酸ジルニニルとのイオ ソ交換反応で同位体分離を行なった硝酸カリウム (7x8)索，カリウム同位体存在比末知の試料として 用いた。

2. 装置

（1）中性子照射は JRR-1 の気送管を用いて行なっ

* 大阪大学工学部 (Faculty of Eng., Osaka Univ.) 
た。照射位置における熱中性子束は 1 ～ $5 \times 10^{11}$ $\mathrm{n} / \mathrm{cm}^{2} / \mathrm{sec}$ と想定される。

（2）放射能測定は，3" $\times 3 "$ の $\mathrm{NaI}(\mathrm{T} 1)$ シソチレータ を検出部とする T.M.C製256チャネル波高分析器 により， ${ }^{42} \mathrm{~K}$ の崩買に伴 $5 \gamma$ 線 $(1.51 \mathrm{MeV})$ のスペ クトロメトリを行なった。

（3）質量分析は，（株）日立謇作所 RMU $6 \mathrm{D}$ 型質量 分析計(表面電離型イオン源, シングルフィラメン ト方式によった。

(4) 発光分光分析は, 島津中型水晶写真器QF-60分 光光度計によった。

\section{III. 同位体比亡分離率の算出法}

天然のカリリウム中には ${ }^{39} \mathrm{~K},{ }^{40} \mathrm{~K},{ }^{41} \mathrm{~K}$ の 3 核種が存在 するが，このうち ${ }^{40} \mathrm{~K}$ の存在百分率は $0.0119 \%$ で, 他 の 2 核種に比較して非常に小さいのでここではこれ を無視し， ${ }^{39} \mathrm{~K}$ と ${ }^{41} \mathrm{~K} の 2$ 核種からなるすのとして考 える。

硝酸カリウム $\left(\mathrm{KNO}_{3}\right)$ を中性子照射した場合, 生成 する放射性核種にはつぎの 5 核種が考えられる。

$\begin{array}{clcc}\text { 生成核㮔 } & \text { 半減期 } & \text { 核 反応 } & \text { 放射化断面積 } \\ { }^{40} \mathrm{~K} & 1.2 \times 10^{9} \mathrm{y} & { }^{39} \mathrm{~K}(n, \gamma) & 3 \pm 2 \mathrm{~b} \\ { }^{42} \mathrm{~K} & 12.51 \mathrm{hr} & { }^{41} \mathrm{~K}(n, \gamma) & 1.0 \pm 0.2 \mathrm{~b} \\ { }^{16} \mathrm{~N} & 7.38 \mathrm{sec} & { }^{15} \mathrm{~N}(n, \gamma) & 24 \pm 8 \mu \mathrm{b} \\ { }^{14} \mathrm{C} & 5,570 \mathrm{y} & { }^{17} \mathrm{O}(n, \alpha) & 0.5 \pm 0.1 \mathrm{~b} \\ { }^{19} \mathrm{O} & 29.4 \mathrm{sec} & { }^{18} \mathrm{O}(n, \gamma) & 0.21 \pm 0.04 \mathrm{mb}\end{array}$

このうち ${ }^{40} \mathrm{~K}$ と ${ }^{14} \mathrm{C}$ は長い半隇期をる ち, 乙か子 ${ }^{14} \mathrm{C}$ は $\beta$ 放射体でるから， ${ }^{42} \mathrm{~K}$ の放射能測定に際し ては問題にならない。 ${ }^{16} \mathrm{~N},{ }^{19} \mathrm{O}$ は中性子照射後短時間 で消滅するから，結局 ${ }^{42} \mathrm{~K}$ の放射能だけを計測するこ とができる。

同位体存在比未知の硝酸カリウムの重量と誘導放射 能を、同時に同条件で照射した標準試料の重量および 誘導放射能と比校することにより，つぎのように同位 体比を算出することができる。

同位体存在比既知の標涑試料中のカリウムの同位体 比は次式によって示される。

$$
\left[{ }^{41} \mathrm{~K} /{ }^{30} \mathrm{~K}\right]_{a}=\frac{R_{41} / A_{41}}{\left(1-R_{41}\right) / A_{39}}
$$

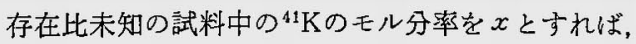
同位体比は次式によって示される。

$$
\left[{ }^{41} \mathrm{~K} /{ }^{39} \mathrm{~K}\right]_{0}=\frac{x}{(1-x)}
$$

未知試料の $\mathrm{KNO}_{3}$ の $b \mathrm{mg}$ 中の ${ }^{41} \mathrm{~K}$ の重量を $D \mathrm{mg}$ とすれば,

$$
D=\frac{a \cdot A \cdot R_{41} \cdot C_{b}}{M_{\mathrm{KNO}_{3}} \cdot C_{a}}=\frac{A \cdot R_{41} \cdot S_{b}}{M \mathrm{KNO}_{3} \cdot S_{a}} \cdot b
$$

が得られる。 $x$ は次式によって示すことができる。

$$
\begin{aligned}
& \frac{A_{41} \cdot x}{A_{41} \cdot x+A_{39}(1-x)+M_{\mathrm{NO}_{3}}}=\frac{D}{b} \\
& x=\frac{\left(A_{39}+M_{\mathrm{NO}_{3}}\right) \cdot D / b}{A_{41}-\left(A_{41}-A_{39}\right) \cdot D / b}
\end{aligned}
$$

(2)，(3)，(5)式から未知試料の同位体比は次式に より求めることができる。

$\left[{ }^{41} \mathrm{~K} /{ }^{39} \mathrm{~K}\right]_{b}$

$$
\begin{gathered}
=\frac{A_{39}\left(1+M_{\left.\mathrm{NO}_{3} / A_{39}\right) \cdot A \cdot R_{41} \cdot S_{b} / S_{a}}\right.}{A_{41} \cdot\left\{M_{\mathrm{KNO}_{3}}-A \cdot R_{41} \cdot S_{b} / S_{a} \cdot\left(1+M_{\mathrm{NO}_{3} / A_{41}}\right)\right\}} \\
\left.\left.=\frac{A_{39}\left(1+M_{\left.\mathrm{NO}_{3} / A_{39}\right) \cdot A \cdot R_{41} \cdot S_{b} / S_{a}}\right.}{A_{41}\left\{A \cdot\left(1-R_{41} \cdot S_{b} / S_{a}\right)\right.}+A \cdot R_{41} / A_{41} \cdot S_{b} / S_{a}\right)\right\}
\end{gathered}
$$

ここで $S_{b} / S_{a} \simeq 1$ であるときは， $R_{41}=0.069$ である ことを考慮すれば，(6)式の分母で $S_{0} / S_{a}=1^{*}$ と考之 て差支えない。また

$$
1-A \cdot R_{41} / A_{41}=A \cdot\left(1-R_{41}\right) / A_{38}
$$

であるから（6)式はつぎのようになる。

$$
\begin{aligned}
{\left[{ }^{41} \mathrm{~K} /{ }^{39} \mathrm{~K}\right]_{b} } & =\frac{A_{39} \cdot A \cdot R_{41} \cdot S_{b} / S_{a}\left(1+M_{\left.\mathrm{NO}_{3} / A_{39}\right)}\right.}{A_{41} \cdot A\left(1-R_{41}\right)\left(1+\mathrm{NO}_{3} / A_{39}\right)} \\
& =\frac{S_{b} / S_{a} \cdot R_{41} / A_{41}}{\left(1-R_{41}\right) / A_{39}} \\
& =\left[{ }^{41} \mathrm{~K} /{ }^{39} \mathrm{~K}\right]_{a} \cdot \frac{S_{b}}{S_{a}}
\end{aligned}
$$

ここで，標準試料の同位体比に対する未知試料の同 位体比を分離率とすれば，分離率 $E$ は次式で示すこと ができる。

$$
E=\left[{ }^{41} \mathrm{~K} /{ }^{39} \mathrm{~K}\right]_{0} /\left[{ }^{41} \mathrm{~K} /{ }^{39} \mathrm{~K}\right]_{a}=\frac{S_{0}}{S_{a}}
$$

分離係数を求める場合は (7) 式で $R_{41}$ は消去されて いるから，同位体存在比が既知の標準試料は不要とな る。すなわち，存在比が未知の試料間の比放射能の比 が 1 に近いものであれば，分離率を求めることができ る。たとえば，イオン交換樹脂を用いて同位体分離を 行なった場合，樹脂相と溶液相とから得た試料に関す る分離率すなわち分離係数を求めることができる。

もし，比放射能の此が 1 からいちじるしくずれる場 合**には標準試料を用い（6)式によって同位体比を 計算することができる。

* たとえば $S_{b} / S_{a}$ の相対誤差が $1 \%$ あれば, $S_{b} / S_{a}$ $\leqq 1 \pm 0.06$ の範囲では $S_{b} / S_{a}=1$ と扰くことができ る。

** 比放射能の比の相対誤差が $1 \%$ であれば，比放射 能の比 $>1 \pm 0.006$ の場合 


\section{IV. 実 験}

標準試料衫よび末知試料の硝酸カリウムはいずれる $110^{\circ} \mathrm{C}$ で $1 \mathrm{hr}$ 乾燥して定量としたのち，約 $100 \mathrm{mg}$ を 精秤し，バラフィン紙て包装して未知試料を䅺準試料 の間にはさみ，照射用ポリェチレン製カプセルにつめ た。

中性子照射は JRR-1 の気送管を用いて $10 \mathrm{~min}$ 行な った。照射後各試料をポリェキレン慗棒ビンに入れ， 試料の偏在を防ぐため $5 \mathrm{ml}$ の水を加えて溶液とし， フ線スペクトロメトリを行なった。

${ }^{42} \mathrm{~K}$ の放射能はスペクトログラムの ${ }^{42} \mathrm{~K} の$ 光電ピー クの面積積分によって求めた。面積積分の方法として は，(1)半值輻と波高値との積を求める方法，(2)光電ピ 一クの全カウント数を加算索方方法、について行なっ た。その結果(2)の方法で得た值の方が(1)の方法で得た 值より ${ }^{42} \mathrm{~K}$ の崩壊曲線上でのバラッキが少なく，(1)の 方法では波启值拝よび半值幅に伴う誤差がかなり大き いるのであると思和れる。

測定は時刻 $t$ を变光て 3 度行ない，崩壊の式 $(N=$ $N_{0} \cdot \mathrm{e}^{-\lambda t}$ ) を用いて一定時点に補外し，各試料について 3 個の測定做を得た。これらの測定值間の偏差の原因 としてはつぎの上5なるのが考えられる。

(1) 放射能計数に伴 5統計誤差 : これは計数時間が 一定であれば、計数率の大小に伴い精度を巽にする。

（2）測定条件に上る誤差：試料の幾何学的位置や測 定器に供給される電圧の変動による。

(3) 波高解析に伴亏器差：測定試料の放射化学的純 度に関係する。高エネルギーの $\boldsymbol{\gamma}$ 放射体が不純物とし て共存するときは, その Compton 效果が ${ }^{42} \mathrm{~K}$ の光電

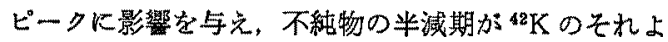
りも小であれば，中性子照射後比輁的早い時期の測定 値を，まな半減期が長いるのを含む場合には，測定時 期の遅い堛合の測定值をそれぞれ增加させ，実際の值 より大きな值を示すことになる。したがってこの場合 には，測定時期により精度が異なるものと考えられる が、ここでは便宜上各测定值とす同等の精度てあると して計算した。

一般に，測定值間の偏差は標準試料には少なく，未 知試料で大きいことが認められ，不純物による誤差 で女ることを示している。以上の考虑から平均值を求 める場合, 偏差の程度か計数誤差の籍囲内にあるもの は，(1)が主要因子であると考方て軽重率付平均值をと り，計数誤差の範囲を超劣るるのについては（2)ない し(3)が主要因子であると考えて算断平均值を求めた。

\section{V. 実験結果と考察}

第 1 表は標华試料と末知試料の比放射能の値を示し たるのてある。この表が示すように，標準試料の比放 射能值の相互間にはかなり大きい差があり、これから 直らに一定の標整健を定めることはでさないてその原 因としては，原子炻内の試料の照射位置における中性 子柬の不均一性と陚料の自己吸収効果な上が考えられ る。これらの検討圭行ならために，試料の配列順序と 比放射能の関係を調ぺた。

第1表 標华試料拈上び末知試料の圠放射能 （試料番号はカプセル中の試料 の配列順序を示するのではない)

\begin{tabular}{c|c||c|c}
\hline $\begin{array}{c}\text { 標準試料 } \\
\text { No. }\end{array}$ & $\begin{array}{c}\text { 比放 射 能 } \\
(\mathrm{cpm} / \mathrm{mg})\end{array}$ & $\begin{array}{c}\text { 末知陚料 } \\
\text { No. }\end{array}$ & $\begin{array}{c}\text { 比 放 射能 } \\
(\mathrm{cpm} / \mathrm{mg})\end{array}$ \\
\hline 1 & $90.6 \pm 0.5$ & 1 & $90.9 \pm 0.6$ \\
2 & $90.3 \pm 0.4$ & 2 & $89.0 \pm 1.0$ \\
3 & $89.5 \pm 0.5$ & 3 & $88.5 \pm 0.7$ \\
4 & $88.9 \pm 0.5$ & 4 & $86.6 \pm 0.4$ \\
5 & $88.6 \pm 0.5$ & 5 & $86.7 \pm 0.7$ \\
6 & $86.2 \pm 0.8$ & 6 & $92.6 \pm 1.8$ \\
7 & $85.7 \pm 0.4$ & 7 & $89.0 \pm 0.8$ \\
8 & $86.3 \pm 0.6$ & 8 & $87.6 \pm 0.6$ \\
9 & $87.5 \pm 0.4$ & 9 & $87.3 \pm 0.4$ \\
10 & $89.6 \pm 0.5$ & 10 & $86.3 \pm 0.7$ \\
11 & $95.5 \pm 0.4$ & 11 & $85.8 \pm 0.8$ \\
\hline
\end{tabular}

試料はパラフィン紙に包み，栖染試料の間に未知試 料をはさみ，第 1 図のように炻心方向端より他方向端 に配列した。このような配列群を A, B 2 群，並列に 1 つのカプセル中につめて照射した。A，B群の配列 の序数と比放射能との関係を第 2 図扎よび第 3 困に示 した。これらの図から明らかなように、いずれの場合 にも試料の配列順序に往って，わずかながら比放射能 の値が減少していることがわかる。この事実から、こ れらの図において標準試料の比放射能の值を直線で結

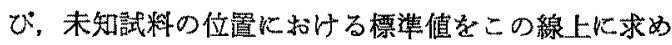
た。この值のすつ標準偏差については，これをはさむ 2 つの標準試料のるつ標準偏差の中の大きい值をむっ

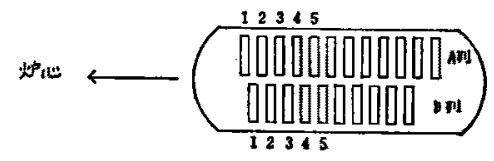

第 1 図 照射カプセル中の試料の配置 


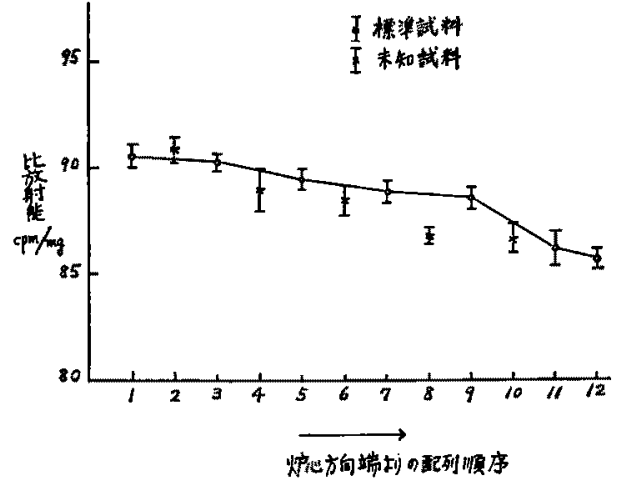

第 2 図 照射陚科の相対位置と 比放射能との関係 (A列)

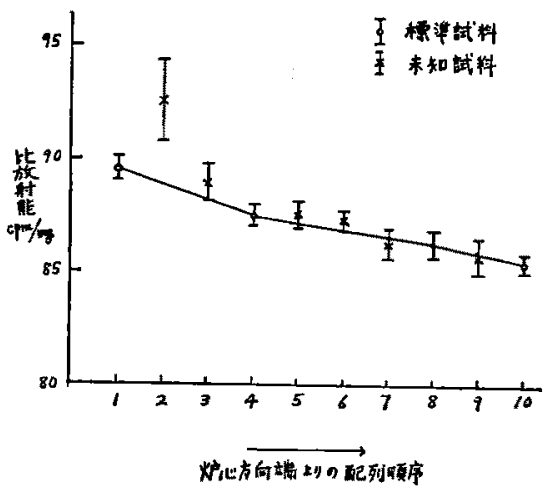

第3图照射試料の相対位固と 比故射能との関倸(B 列)

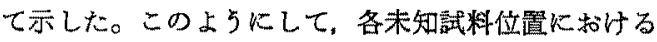
それぞれの標準值を定め、これによって補正した值を 用いて (8)式により*分離率を計算した。第 2 表はこ のようにして得た結果と筫量分析の結果とを比較対照

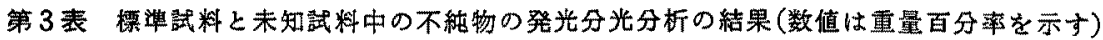

\begin{tabular}{|c|c|c|c|c|c|c|}
\hline 試料名 元素種 & $\mathrm{Mg}$ & $\mathrm{Cu}$ & $\mathrm{Si}$ & $\mathrm{Al}$ & $\mathrm{Ca}$ & $\mathrm{Na}$ \\
\hline 標溥試料(特級試菜) & $7 \times 10^{-4}$ & 0 & $5 \times 10^{-5}$ & $5 \times 10^{-3}$ & $1 \times 10^{-3}$ & 0 \\
\hline $\begin{array}{l}\text { 標準試料（特訯試楽を } \\
\text { 再結晶したすの） } \\
\end{array}$ & $<5 \times 10^{-5}$ & 0 & $5 \times 10^{-5}$ & $<5 \times 10^{-5}$ & $5 \times 10^{-5}$ & 0 \\
\hline 未 知 試 料 No.6 & $5 \times 10^{-5}$ & $5 \times 10^{-5}$ & $1 \times 10^{-4}$ & $<5 \times 10^{-5}$ & $3 \times 10^{-4}$ & $1 \times 10^{-3}$ \\
\hline 未 知 試 料 No.7 & $<5 \times 10^{-5}$ & 0 & $5 \times 10^{-5}$ & $<5 \times 10^{-5}$ & $<5 \times 10^{-5}$ & $5 \times 10^{-5}$ \\
\hline
\end{tabular}

な考剫をすれば，さらに精度を上げることができると 思われる。第 2 に試料の秤量に及伍子不純物の影響が あるが，第3表によれば，不純物の等与は視しらる 程度であることがわかる。

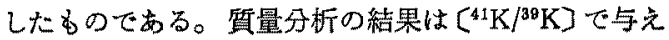
られるから，次式によって分離率 $E$ を求めた。 $E=\left[{ }^{41} \mathrm{~K} /{ }^{38} \mathrm{~K}\right]$ 未知詰料 $/\left[{ }^{41} \mathrm{~K} /{ }^{38} \mathrm{~K}\right]$ 標染試料

第 2 表 故射化分析と質量分析から求めた 分離率の比較

\begin{tabular}{c|c|c}
\hline \multirow{2}{*}{$\begin{array}{c}\text { 試 料 } \\
\text { No. }\end{array}$} & 分 & \multicolumn{2}{|c}{ 離 } \\
\cline { 2 - 3 } & 放射化分析值 & 質量分析值 \\
\hline 1 & $1.005 \pm 0.013$ & - \\
2 & $0.991 \pm 0.014$ & - \\
3 & $0.992 \pm 0.014$ & $0.999 \pm 0.004$ \\
4 & $0.977 \pm 0.010$ & $0.983 \pm 0.005$ \\
5 & $0.991 \pm 0.018$ & - \\
6 & $1.04 \pm 0.02$ & $1.025 \pm 0.003$ \\
7 & $1.008 \pm 0.016$ & $0.996 \pm 0.004$ \\
8 & $1.004 \pm 0.014$ & - \\
9 & $1.004 \pm 0.012$ & - \\
10 & $0.996 \pm 0.017$ & - \\
11 & $0.999 \pm 0.015$ & - \\
\hline
\end{tabular}

第 2 表に示す上うに，放射化分析によって得られた 結果の精度は質量分析の場合の約 110 で出る。この原 因として，第 1 に試料の放射化学的純度の問題が考え られる。第 3 表社標準試料括よび一部の末知試料につ いての発光分光分析の結果であり，標準試料に比べて 未知試料の純度は低い。これは同位体分離の過程で混 入し，照射前の精製の際に除去することができなかっ たものと思われる。たとえば，第 2 表の未知試料No.6 に見られ万質量分析值との差異は，中性子照射の際。 ${ }^{23} \mathrm{Na}(n, \gamma){ }^{24} \mathrm{Na}$ 反応で生じた半隇期15 hr の ${ }^{24} \mathrm{Na}$ 中, その他微量な長寿命 $\gamma$ 放射体などによる ${ }^{42} \mathrm{~K}$ の光電ピ 一クに対する笴与の結果であるらと思われる。したが って，不純物の核種を知り，放射能湘定に際して適当 


\section{VI. 結語}

放射化分析により同位体比をたは分離率を求める場

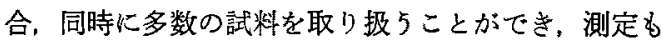
比較的簡単であるが，試料の化学形が一定で安定なる のを必要とし，目的とする同位体の放射化断面積と生 成する核種の放射能の半減期が適当なるのでなければ ならないため，対象性限定される。さらに誤差を生ず る機会が多く，精度は質量分析法に劣る。しかし，多 数の試料を簡便にある程度の見通しをつけるような場 合には，充分目的にかな 5 ものと考学られる。

最後に, 本研究は日本原子力研究所の大学共同利用 の一環の研究として行なったものであり，深く感謝す るとともに，質量分析を快く引き受けて下さった(株) 日立製作所中央研究所の岡本潤一氏と研究室の方々， また発光分光分析をして下さった松下電子工業(株)研 究所の分析課の方々に厚く感謝するものである。

(1964年 9 月 4 日 受理)

〔記 号〕

A: カリウムの原子量

$A_{39}:{ }^{39} \mathrm{~K}$ の質量, $\quad A_{41}:{ }^{41} \mathrm{~K}$ の質量 $a ：$ 中性子照射した標洹試料の重量 (mg)

$b$ ：中性子照射した未知試料の重量 (mg)

$C_{a}$ ：標運試料中に生成した ${ }^{42} \mathrm{~K}$ の放射能 (cpm)

$C_{b}$ : 末知試料中に生成した ${ }^{42} \mathrm{~K}$ の放射能 (cpm) $M_{\mathrm{KNO}_{3}}: \mathrm{KNO}_{3}$ の分子量

$M_{\mathrm{NO}}: \mathrm{NO}_{3}$ の分子量

$R_{41}$ ：橪染試料中の ${ }^{41} \mathrm{~K}$ の同位体存在出(重量)

$S_{a}$ ：標準試料の比放射能 (cpm/mg)

$S_{b}$ : 末知試料の比放射能 $(\mathrm{cpm} / \mathrm{mg})$

\section{一参考 文 献—}

(1) H.WÄnke, E.U.MONSE: Z. Naturforsch., 16a, 667 (1955).

(2) E.MERZ, W.HERR: A/Conf., P/984, (1958),

(3) T.IsHIMORI, T.FuJINO: 本 誌, 4, [1], 16(1962)

(4) L.P.Bilibin, A.A.Lbov, I.I.Naumova: At. Energ., 10, 528 (1961).

(5) M.MoHnke: Kernenergie, 5, 436 (1962).

（6）木村煡二郎：放射線データーブック，(1958），地 人書館。

（7）品川睦明, 大吉昭，大吉慣美于：第 1 回化学·化学 工学分科会予稿集, p. 7, (1963).

(8) M. Shinagawa, A. Ōyoshi, E. Ōyoshi: $J$. Nucl. Sci. Technol., 1, 362 (1964).

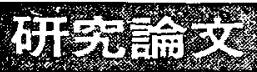

\section{3. 原子力発電所災害防止施設の放射能放出抑制機能の検討}

\author{
田上嵩* \\ Considerations on Fission Product Release Reduction Factors \\ of Post Incident Devices for Nuclear Power Plants
}

By Takashi TAGAMI

It is shown that in a loss of coolant accident of a nuclear power plant the amount of a specified nuclide amoung fission products released to atmosphere from the post incident device system consisting of an $\mathrm{N}$-fold multiple barrier can be approximately estimated by the simple formula

where

$$
Q_{L}=\alpha_{m} Q_{0} K_{0} K_{1} K_{2} \cdots \cdots \cdots \cdot K_{N}
$$

$$
K_{n}=\frac{\alpha_{n} \beta_{n}}{\lambda+\beta_{n}+\xi_{n},} \quad(n=0,1,2, \cdots \cdots \cdots, N)
$$

is a F.P. release reduction factor associated with the $n$-th barrier, $Q_{0}$ represents core
*（株)日立製作所中央研究所(Hitachi Central Res. Lab., Hitachi, Ltd.) 